\title{
Severe Motor Weakness Due to Disturbance in Peripheral Nerves Following Tisagenlecleucel Treatment
}

\author{
MAI KUBOKI ${ }^{1}$, YOSHIHIRO UMEZAWA ${ }^{1}$, YOTARO MOTOMURA ${ }^{1}$, KEIGO OKADA $^{1}$, \\ AYAKO NOGAMI $^{1,2}$, TOSHIKAGE NAGAO ${ }^{1}$, OSAMU MIURA ${ }^{1}$ and MASAHIDE YAMAMOTO ${ }^{1}$ \\ ${ }^{1}$ Department of Hematology, Tokyo Medical and Dental University, Tokyo, Japan; \\ ${ }^{2}$ Department of Clinical Laboratory, Tokyo Medical and Dental University, Tokyo, Japan
}

\begin{abstract}
Background: Neurotoxicity is one of the dangerous complications of chimeric antigen receptor (CAR) T-cell therapy, while its pathophysiology remains to be fully understood. Motor weakness not associated with central nervous system (CNS) toxicity has rarely been reported after CAR T-cell therapy. Case Report: A 42-year-old female with a refractory diffuse large $B$-cell lymphoma received tisagenlecleucel (tisa-cel) and developed cytokine release syndrome (CRS) on day 3. She was treated with tocilizumab and methylprednisolone, which resolved CRS promptly. On day 7, motor weakness in lower extremities appeared, and she gradually became unable to walk without showing any other symptoms attributed to CNS disturbances. Whereas dexamethasone and tocilizumab were ineffective, neuropathy improved after high dose chemotherapy followed by autologous stem cell transplantation. Nerve conduction study (NCS) in lower extremities showed a decline in compound muscle action potential amplitude along with worsening of motor weakness, which was restored after improvement of symptoms. Based on symptoms and NCS, her motor weakness was thought to be due to disturbance in peripheral nerves. Conclusion: This study reports a patient who developed severe motor weakness due to disturbance in peripheral nerves after tisa-cel therapy. Neurotoxicity of non-CNS origin should also be noted in CAR T-cell therapy.
\end{abstract}

This article is freely accessible online.

Correspondence to: Yoshihiro Umezawa, Department of Hematology, Tokyo Medical and Dental University, 1-5-45 Yushima, Bunkyo-Ku, Tokyo 113-8519 Japan. Tel: +81 358035211, e-mail: umehema@tmd.ac.jp

Key Words: Chimeric antigen receptor T-cell therapy, Tisagenlecleucel, motor weakness, disturbance in peripheral nerves, diffuse large B-cell lymphoma.
Anti-CD19 chimeric antigen receptor (CAR) T-cells are a groundbreaking treatment option for relapsed or refractory B-cell malignancies(1-7). Tisagenlecleucel (tisa-cel) is an anti-CD19 CAR T-cell therapy that was approved in 2017 by the Food and Drug Administration followed by rapid worldwide spread (8). While tisa-cel has shown dramatic results, it can cause unique adverse effects, such as cytokine release syndrome (CRS) and immune effector cell-associated neurotoxicity syndrome (ICANS) (9-11). ICANS is defined by the American Society for Transplantation and Cellular Therapy (ASTCT) toxicity consensus group, and the spectrum of neurological symptoms ranges from delirium and language dysfunction to seizures and coma (12). Cognitive impairment is the most common symptom, and it is usually resolved by appropriate therapy. On the other hand, there are few reports on motor weakness associated with CAR T-cell therapies, the details of which remain unclear (13-16).

Herein, we report a case of severe motor weakness possibly due to disturbance in peripheral nerves occurring after tisa-cel therapy in a patient with relapsed diffuse large B-cell lymphoma (DLBCL). Her neurological symptoms were thought to be limited to those attributable to peripheral nerves and were irresponsive to dexamethasone.

\section{Case Report}

A 42-year-old woman with relapsed/refractory diffuse large B-cell lymphoma (DLBCL) was admitted to our hospital to receive CAR T-cell therapy. Four years before, she was diagnosed with CD5-positive DLBCL. She achieved complete response (CR) after eight cycles of dose adjusted EPOCH-R [etoposide (ETP), prednisolone, vincristine (VCR), cyclophosphamide (CPA), doxorubicin (DXR) and rituximab (R)], followed by two cycles of high-dose methotrexate (MTX) for CNS prophylaxis. Three years later, she had a relapse with the left inguinal lymph node. Salvage chemotherapy and autologous peripheral blood stem cell 
(PBSC) harvest were performed; however, her disease progressed before autologous transplantation. The patient was admitted to our hospital and underwent leukapheresis for creating the tisa-cel.

She received tisa-cel after lymphodepletion chemotherapy with fludarabine and CPA. The clinical course is illustrated in Figure 1. Three days after tisa-cel infusion, she developed CRS with high fever, tachycardia, and headache and was treated with tocilizumab, followed by intravenous methylprednisolone (mPSL). CRS was immediately resolved after starting mPSL. Motor weakness in both lower limbs without any symptoms attributed to CNS disturbance such as aphasia and impaired consciousness, appeared from day 7 and gradually progressed. Physical exam showed a decrease in deep tendon reflex in all four limbs. Magnetic resonance imaging (MRI) of the brain and the whole spine showed no abnormal findings and cerebrospinal fluid examination showed no abnormalities in total protein, cell count, or cytology. A motor nerve conduction study (NCS) was performed in right tibial nerve. Compound muscle action potentials (CMAPs) were recorded from abductor hallucis muscle and electrical stimulation was delivered at the ankle and popliteal fossa. The distal CMAP amplitude (normal lower limit; $13.4 \mathrm{mV}$ ) and motor nerve conduction velocity (MCV) (normal lower limit; $43.7 \mathrm{~m} / \mathrm{s}$ ) were normal, $17.6 \mathrm{mV}$ and $45.5 \mathrm{~m} / \mathrm{s}$, respectively (Table I). Although it is not typical, we considered her motor weakness as ICANS since it developed after CRS. Motor weakness of the lower limbs continued to progress, and she was unable to walk. She was treated with dexamethasone from day 29 , but her symptoms did not improve. Simultaneously, lymphoma progressed to the para-aortic lymph node and local radiotherapy was started. Radiotherapy was discontinued due to severe cytopenia. A bone marrow smear was significantly hypocellular and showed no infiltration of lymphoma cells, and administration of filgrastim was ineffective. After starting filgrastim, a high fever was observed again. Since the clinical symptoms were similar to those of the first CRS, we considered the fever to be a CRS-like symptom and started tocilizumab. The high fever improved promptly, but the neurological symptoms were completely unaffected. The patient's lymphoma gradually worsened thereafter, but the severity of the cytopenia made it difficult to continue therapy. Therefore, we decided to perform an autologous PBSC transplant (aPBSCT) using the previously collected PBSCs. She returned to the previous hospital. The NCS showed a significant drop in the distal CMAP amplitude (5.4 $\mathrm{mV}$ ) on day 71 when her motor weakness worsened (Table I), and the patient was unable to walk. After she received high-dose chemotherapy with R-MEAM(17) followed by aPBSCT on day 81 , she achieved a CR with full neutrophil recovery. Her motor weakness which had persisted over two months from the onset, gradually improved after aPBSCT, and she regained the ability to walk with a caster walker for a short distance. The distal CMAP amplitude on NCS was restored to $13.5 \mathrm{mV}$ on day 179 (Table I).

\section{Discussion}

Neurotoxicity caused by anti-CD19 CAR T-cell therapy has been reported in $20 \%-60 \%$ of patients (3-7). For tisa-cel, neurologic events were reported in $21 \%$ of patients $(12 \% \geq$ Grade 3) for relapsed/refractory DLBCL and $40 \%$ of patients $(13 \% \geq$ Grade 3$)$ for relapsed/refractory B cell acute lymphoblastic leukemia $(5,6)$. Neurotoxicity after CAR Tcell therapy was previously termed CAR T-cell related encephalopathy (CRES), but is now referred to as ICANS due to the observation of similar neurotoxicity after other cell-based immunotherapies (12).

ICANS, like CRS, is a severe adverse effect of CAR Tcell therapy, and the mechanisms are poorly understood. Motor weakness is a symptom of ICANS; however, there have been a few reports on motor weakness after CAR T-cell therapy (13-16). In a report specific to neurotoxicity following CAR T-cell therapy, 11 cases of focal weakness were reported (15). In that report, many cases were complicated by encephalopathy-related symptoms such as aphasia, suggesting that the motor weakness originated from the CNS. The ASTCT defines ICANS as a disorder characterized by a pathologic process involving the CNS (12). In our case, there was no evidence of CNS lymphoma invasion and no other disease explaining motor weakness, suggesting that it was related to the CAR T-cell therapy. However, since the decreased CMAP amplitude was seen only when the motor weakness was the most severe in her clinical course, the neurotoxicity was thought to have emerged through a non-CNS mechanism. Previous studies have reported a few cases of neuropathy after CAR-T cells (14) and Guillain-Barré syndrome has been reported with cell-based immunotherapy other than CD19 CAR T-cells (18). This suggests that the neurotoxicity of non-CNS origin may also be observed in some patients.

Steroid treatment is recommended for treating severe neurotoxicity $(9,19)$; however, most reports are based on CNS-related neurotoxicity, and the efficacy of steroids for the disturbance in peripheral nerves is unknown. In our case, steroids, as well as tocilizumab, were completely ineffective, and the symptoms improved after high-dose chemotherapy followed by aPBSCT. Previous reports have shown that CPA, anti-thymocyte globulin, and intrathecal chemotherapy, which directly affect $\mathrm{T}$ lymphocytes, are effective in cases of steroid/tocilizumab refractory neurotoxicity (20-22). CAR and non-CAR T-cells have been reported to infiltrate the cerebrospinal fluid and brain parenchyma, consistent with encephalitis, in a non-human primate model (23). It is thought that some neurotoxicity may be caused and maintained by CAR and non-CAR Tcell infiltration, and removal of these cells may have allowed the patient to recover from the severe neurotoxicity. 


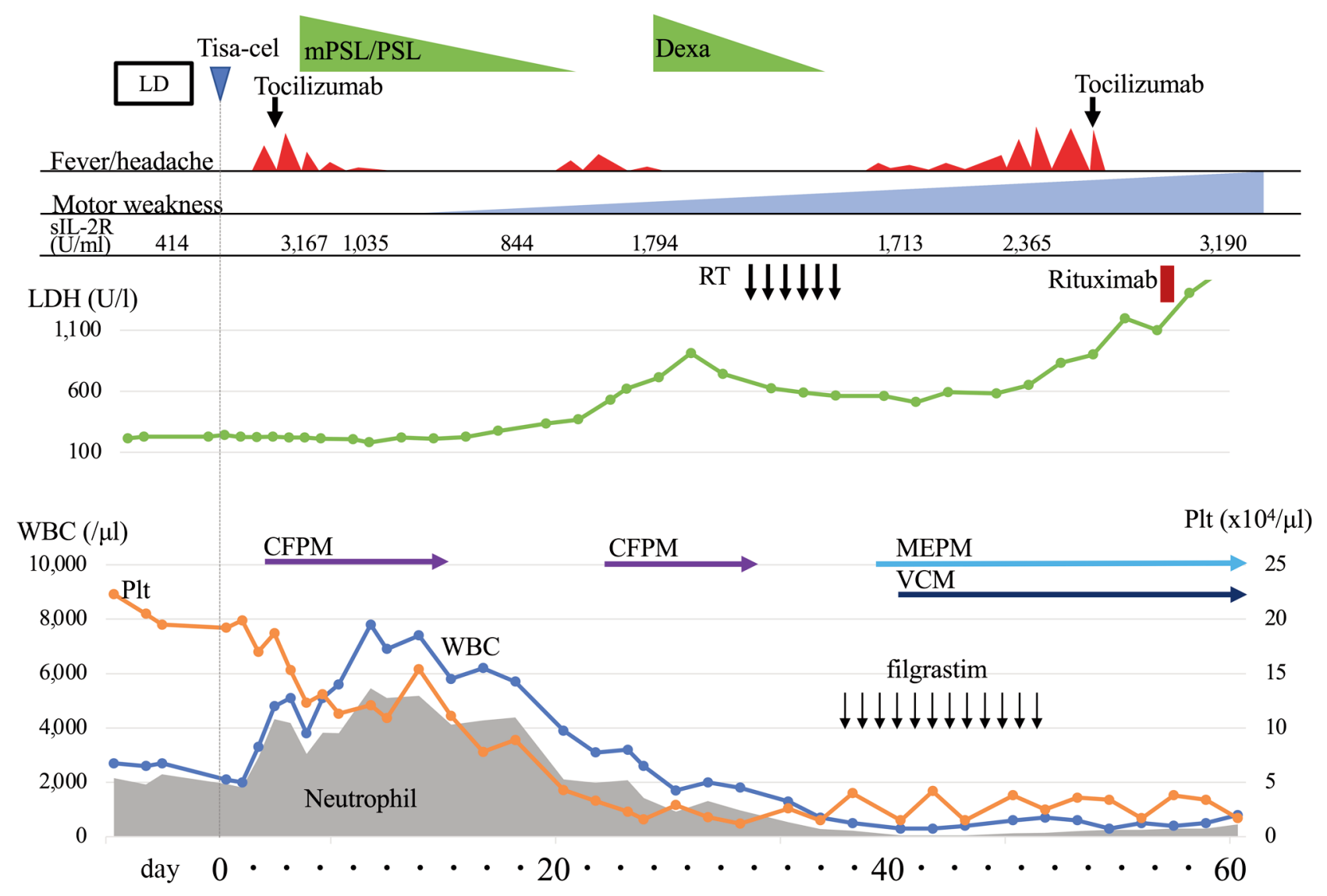

Figure 1. Clinical course after tisa-cel infusion. CFPM, Cefepime; Dexa, dexamethasone; RT, radiation therapy; LD, lymphodepletion; LDH, lactate dehydrogenase; mPSL, methylprednisolone; MEPM, meropenem; Plt, platelet; PSL, prednisolone; sIL-2R, soluble interleukin-2 receptor; Tisa-cel, tisagenlecleucel; VCM, vancomycin; WBC, white blood cell.

Table I. Nerve conduction study of the right tibial nerve.

\begin{tabular}{|c|c|c|c|c|c|c|}
\hline \multirow[b]{2}{*}{ Stimulation site } & \multicolumn{2}{|c|}{ Day 24} & \multicolumn{2}{|c|}{ Day 71} & \multicolumn{2}{|c|}{ Day 179} \\
\hline & Ankle & Knee & Ankle & Knee & Ankle & Knee \\
\hline CMAP Amplitude, mV & 17.6 & 13.6 & 5.4 & 4.2 & 13.5 & 9.6 \\
\hline $\mathrm{MCV}, \mathrm{m} / \mathrm{s}$ & \multicolumn{2}{|c|}{45.5} & \multicolumn{2}{|c|}{43.2} & \multicolumn{2}{|c|}{49.3} \\
\hline
\end{tabular}

Day 24; initial phase of worsening motor weakness, day 71; advanced phase that the patient was not walking, day 179; restoring phase that the patient could walk for short distances. MCV, motor nerve conduction velocity; CMAP, compound muscle action potential.

\section{Conclusion}

In this report, we described a patient with motor weakness without CNS disorder following treatment with tisa-cel. Most cases of neurotoxicity are related to the CNS in patients treated with tisa-cel, but neurotoxicity not originating in the CNS should also be noted. Further research is required to reveal the mechanism of non-CNS related neurotoxicity, which will lead to optimal diagnosis and patient management.

\section{Conflicts of Interest}

The Authors declare that they have no competing interests. 


\section{Authors' Contributions}

M.K., Y.U. and M.Y. provided concept and design; M.K., Y.U., O.M. and M.Y. wrote and reviewed the manuscript; M.K., Y.U., Y.M., K.O., A.N., T.N. and M.Y. acquired data and managed the patient.

\section{Acknowledgements}

We thank Dr. Akaza and Dr. Nishida from the department of neurology and neurological science of Tokyo Medical and Dental University for general advice on neurological findings and examinations. We also thank the Cell Processing Center of Tokyo Medical and Dental University for their collaboration on the patient CAR T-cell therapy.

\section{References}

1 Mohty M, Gautier J, Malard F, Aljurf M, Bazarbachi A, Chabannon C, Kharfan-Dabaja MA, Savani BN, Huang H, Kenderian S, Nagler A and Perales MA: CD19 chimeric antigen receptor-T cells in B-cell leukemia and lymphoma: current status and perspectives. Leukemia 33(12): 2767-2778, 2019. PMID: 31690821. DOI: 10.1038/s41375-019-0615-5

2 Rallis KS, Hillyar CRT, Sideris M and Davies JK: T-cell-based immunotherapies for haematological cancers, part B: A SWOT analysis of adoptive cell therapies. Anticancer Res 41(3): 11431156, 2021. PMID: 33788705. DOI: 10.21873/anticanres.14871

3 Neelapu SS, Locke FL, Bartlett NL, Lekakis LJ, Miklos DB, Jacobson CA, Braunschweig I, Oluwole OO, Siddiqi T, Lin Y, Timmerman JM, Stiff PJ, Friedberg JW, Flinn IW, Goy A, Hill BT, Smith MR, Deol A, Farooq U, McSweeney P, Munoz J, Avivi I, Castro JE, Westin JR, Chavez JC, Ghobadi A, Komanduri KV, Levy R, Jacobsen ED, Witzig TE, Reagan P, Bot A, Rossi J, Navale L, Jiang Y, Aycock J, Elias M, Chang D, Wiezorek J and Go WY: Axicabtagene ciloleucel CAR T-cell therapy in refractory large B-cell lymphoma. N Engl J Med 377(26): 2531-2544, 2017. PMID: 29226797. DOI: 10.1056/NEJMoa1707447

4 Park JH, Rivière I, Gonen M, Wang X, Sénéchal B, Curran KJ, Sauter C, Wang Y, Santomasso B, Mead E, Roshal M, Maslak P, Davila M, Brentjens RJ and Sadelain M: Long-term followup of CD19 CAR therapy in acute lymphoblastic leukemia. N Engl J Med 378(5): 449-459, 2018. PMID: 29385376. DOI: 10.1056/NEJMoa1709919

5 Schuster SJ, Bishop MR, Tam CS, Waller EK, Borchmann P, McGuirk JP, Jäger U, Jaglowski S, Andreadis C, Westin JR, Fleury I, Bachanova V, Foley SR, Ho PJ, Mielke S, Magenau JM, Holte H, Pantano S, Pacaud LB, Awasthi R, Chu J, Anak Ö, Salles G, Maziarz RT and JULIET Investigators: Tisagenlecleucel in adult relapsed or refractory diffuse large Bcell lymphoma. N Engl J Med 380(1): 45-56, 2019. PMID: 30501490. DOI: 10.1056/NEJMoa1804980

6 Maude SL, Laetsch TW, Buechner J, Rives S, Boyer M, Bittencourt H, Bader P, Verneris MR, Stefanski HE, Myers GD, Qayed M, De Moerloose B, Hiramatsu H, Schlis K, Davis KL, Martin PL, Nemecek ER, Yanik GA, Peters C, Baruchel A, Boissel N, Mechinaud F, Balduzzi A, Krueger J, June CH, Levine BL, Wood P, Taran T, Leung M, Mueller KT, Zhang Y, Sen K, Lebwohl D, Pulsipher MA and Grupp SA: Tisagenlecleucel in children and young adults with B-cell lymphoblastic leukemia. N Engl J Med 378(5): 439-448, 2018. PMID: 29385370. DOI: 10.1056/NEJMoa1709866

7 Abramson JS, Palomba ML, Gordon LI, Lunning MA, Wang M, Arnason J, Mehta A, Purev E, Maloney DG, Andreadis C, Sehgal A, Solomon SR, Ghosh N, Albertson TM, Garcia J, Kostic A, Mallaney M, Ogasawara K, Newhall K, Kim Y, Li D and Siddiqi $\mathrm{T}$ : Lisocabtagene maraleucel for patients with relapsed or refractory large B-cell lymphomas (TRANSCEND NHL 001): a multicentre seamless design study. Lancet 396(10254): 839-852, 2020. PMID: 32888407. DOI: 10.1016/S0140-6736(20)31366-0

8 Pasquini MC, Hu ZH, Curran K, Laetsch T, Locke F, Rouce R, Pulsipher MA, Phillips CL, Keating A, Frigault MJ, Salzberg D, Jaglowski S, Sasine JP, Rosenthal J, Ghosh M, Landsburg D, Margossian S, Martin PL, Kamdar MK, Hematti P, Nikiforow S, Turtle C, Perales MA, Steinert P, Horowitz MM, Moskop A, Pacaud L, Yi L, Chawla R, Bleickardt E and Grupp S: Real-world evidence of tisagenlecleucel for pediatric acute lymphoblastic leukemia and non-Hodgkin lymphoma. Blood Adv 4(21): 5414-5424, 2020. PMID: 33147337. DOI: 10.1182/bloodadvances.2020003092

9 Yakoub-Agha I, Chabannon C, Bader P, Basak GW, Bonig H, Ciceri F, Corbacioglu S, Duarte RF, Einsele H, Hudecek M, Kersten MJ, Köhl U, Kuball J, Mielke S, Mohty M, Murray J, Nagler A, Robinson S, Saccardi R, Sanchez-Guijo F, Snowden JA, Srour M, Styczynski J, Urbano-Ispizua A, Hayden PJ and Kröger $\mathrm{N}$ : Management of adults and children undergoing chimeric antigen receptor T-cell therapy: best practice recommendations of the European Society for Blood and Marrow Transplantation (EBMT) and the Joint Accreditation Committee of ISCT and EBMT (JACIE). Haematologica 105(2): 297-316, 2020. PMID: 31753925. DOI: 10.3324/haematol.2019.229781

10 Schubert ML, Schmitt M, Wang L, Ramos CA, Jordan K, MüllerTidow C and Dreger P: Side-effect management of chimeric antigen receptor (CAR) T-cell therapy. Ann Oncol 32(1): 34-48, 2021. PMID: 33098993. DOI: 10.1016/j.annonc.2020.10.478

11 Sheth VS and Gauthier J: Taming the beast: CRS and ICANS after CAR T-cell therapy for ALL. Bone Marrow Transplant 56(3): 552-566, 2021. PMID: 33230186. DOI: 10.1038/s41409020-01134-4

12 Lee DW, Santomasso BD, Locke FL, Ghobadi A, Turtle CJ, Brudno JN, Maus MV, Park JH, Mead E, Pavletic S, Go WY, Eldjerou L, Gardner RA, Frey N, Curran KJ, Peggs K, Pasquini M, DiPersio JF, van den Brink MRM, Komanduri KV, Grupp SA and Neelapu SS: ASTCT consensus grading for cytokine release syndrome and neurologic toxicity associated with immune effector cells. Biol Blood Marrow Transplant 25(4): 625-638, 2019. PMID: 30592986. DOI: 10.1016/j.bbmt.2018. 12.758

13 Gust J, Hay KA, Hanafi LA, Li D, Myerson D, Gonzalez-Cuyar LF, Yeung C, Liles WC, Wurfel M, Lopez JA, Chen J, Chung D, Harju-Baker S, Özpolat T, Fink KR, Riddell SR, Maloney DG and Turtle CJ: Endothelial activation and blood-brain barrier disruption in neurotoxicity after adoptive immunotherapy with CD19 CAR-T cells. Cancer Discov 7(12): 1404-1419, 2017. PMID: 29025771. DOI: 10.1158/2159-8290.CD-17-0698

14 Santomasso BD, Park JH, Salloum D, Riviere I, Flynn J, Mead E, Halton E, Wang X, Senechal B, Purdon T, Cross JR, Liu H, Vachha B, Chen X, DeAngelis LM, Li D, Bernal Y, Gonen M, Wendel HG, Sadelain M and Brentjens RJ: Clinical and biological correlates of neurotoxicity associated with CAR T-cell therapy in patients with B-cell acute lymphoblastic leukemia. 
Cancer Discov 8(8): 958-971, 2018. PMID: 29880584. DOI: 10.1158/2159-8290.CD-17-1319

15 Rubin DB, Danish HH, Ali AB, Li K, LaRose S, Monk AD, Cote DJ, Spendley L, Kim AH, Robertson MS, Torre M, Smith TR, Izzy S, Jacobson CA, Lee JW and Vaitkevicius $\mathrm{H}$ : Neurological toxicities associated with chimeric antigen receptor T-cell therapy. Brain 142(5): 1334-1348, 2019. PMID: 30891590. DOI: 10.1093/brain/awz053

16 Belin C, Devic P, Ayrignac X, Dos Santos A, Paix A, SirvenVillaros L, Simard C, Lamure S, Gastinne T, Ursu R, Berger C, Platon L, Tessoulin B, Azoulay E, Wallet F, Thieblemont C, Bachy E, Cartron G, Laplaud DA and Carpentier AF: Description of neurotoxicity in a series of patients treated with CAR T-cell therapy. Sci Rep 10(1): 18997, 2020. PMID: 33149178. DOI: 10.1038/s41598-020-76055-9

17 Sugimoto M, Ito S, Mashima K, Umino K, Minakata D, Nakano H, Yamasaki R, Kawasaki Y, Ashizawa M, Yamamoto C, Fujiwara S, Okazuka K, Hatano K, Sato K, Oh I, Ohmine K, Suzuki T, Muroi K, Kako S and Kanda Y: Retrospective evaluation of the MEAM regimen as a conditioning regimen before autologous peripheral blood stem cell transplantation for lymphoma in two centers with different dosing schedules of melphalan. Ann Hematol 95(9): 1513-1519, 2016. PMID: 27365141. DOI: $10.1007 / \mathrm{s} 00277-016-2740-9$

18 Joseph J, Nathenson MJ, Trinh VA, Malik K, Nowell E, Carter K, Weathers SP, Demetri GD, Araujo D and Conley AP: Guillain-Barre syndrome observed with adoptive transfer of lymphocytes genetically engineered with an NY-ESO-1 reactive T-cell receptor. J Immunother Cancer 7(1): 296, 2019. PMID: 31703609. DOI: 10.1186/s40425-019-0759-x

19 Neelapu SS, Tummala S, Kebriaei P, Wierda W, Gutierrez C, Locke FL, Komanduri KV, Lin Y, Jain N, Daver N, Westin J, Gulbis AM, Loghin ME, de Groot JF, Adkins S, Davis SE, Rezvani K, Hwu P and Shpall EJ: Chimeric antigen receptor Tcell therapy - assessment and management of toxicities. Nat Rev Clin Oncol 15(1): 47-62, 2018. PMID: 28925994. DOI: 10.1038/nrclinonc.2017.148
20 Garfall A, Lancaster E, Stadtmauer E, Lacey S, Dengel K, Ambrose D, Chen F, Gupta M, Kulikovskaya I, Vogl D, Plesa G, Weiss B, Ferthio R, Richardson C, Melenhorst J, Levine B, June $\mathrm{C}$, Milone $\mathrm{M}$ and Cohen A: Posterior reversible encephalopathy syndrome (PRES) after infusion of anti-Bcma CAR T cells (CART-BCMA) for multiple myeloma: Successful treatment with cyclophosphamide. Blood 128(22): 5702-5702, 2019. DOI: $10.1182 /$ blood.V128.22.5702.5702

21 Wang M, Jain P, Chi TL, Chen SE, Heimberger A, Weathers SP, Zheng L, Rao AV and Rossi JM: Management of a patient with mantle cell lymphoma who developed severe neurotoxicity after chimeric antigen receptor T-cell therapy in ZUMA-2. J Immunother Cancer 8(2): 2020. PMID: 33067318. DOI: 10.1136/jitc-2020-001114

22 Shah NN, Johnson BD, Fenske TS, Raj RV and Hari P: Intrathecal chemotherapy for management of steroid-refractory CAR T-cell-associated neurotoxicity syndrome. Blood Adv 4(10): 2119-2122, 2020. PMID: 32407473. DOI: 10.1182/ bloodadvances 2020001626

23 Taraseviciute A, Tkachev V, Ponce R, Turtle CJ, Snyder JM, Liggitt HD, Myerson D, Gonzalez-Cuyar L, Baldessari A, English C, Yu A, Zheng H, Furlan SN, Hunt DJ, Hoglund V, Finney O, Brakke H, Blazar BR, Berger C, Riddell SR, Gardner $\mathrm{R}$, Kean LS and Jensen MC: Chimeric antigen receptor T cellmediated neurotoxicity in nonhuman primates. Cancer Discov 8(6): 750-763, 2018. PMID: 29563103. DOI: 10.1158/21598290.CD-17-1368
Received July 16, 2021

Revised August 26, 2021 Accepted August 30, 2021 